\title{
The effects of great cold upon magnetism
}

\section{John Trowbridge}

To cite this article: John Trowbridge (1881) The effects of great cold upon magnetism, Philosophical Magazine Series 5, 11:69, 393-394, DOI: 10.1080/14786448108627033

To link to this article: http://dx.doi.org/10.1080/14786448108627033

曲 Published online: 08 Jun 2010.

Submit your article to this journal 준

Џ Article views: 2

Q View related articles $₫$ 
bodies, with a view to determine if certain small specific variations may not have escaped notice, owing to their not hating been searched for, on account of the bias of preconceived ideas, and the lethargy produced by the influence of preformed theories. Crystalline bodies of birefracting properties \&c. which, in relation to the luminiferous æther, are permeable to light with different velocities in different directions, may specially suggest themselves for experiment.

Since the successful pursuit of a research of this kind, where specific differences of a very minute character are in question, wonld no doubt entail considerable experimental resources, with refined and delicate apparatus, which might not be at the disposal of every one, the more therefore does it become desirable to attract general attention to the subject. The comparative dearth of discovery of any great physical principle (of a fundamental character at least) within the last few years would seem, if any thing, to call for additional zeal in experimental enterprise. Although a negative result to the investigations would not be decisive one way or the other in regard to the validity of the explanation of gravity afforded by the kinetic theory (for, of course, it is well conceivable that such specific variations in gravific effect, if they exist, might be too minute for detection with the appliances at our command), yet a positive result would be so highly interesting and important, that even a small prospect of success would amply repay the labour of a careful trial, and enlist usefully the skill and ingenuity of experimenters.

Heatherfield, Bournemouth, March 2, 1881.

LIV. Intelligence and Miscellaneous Articles.

THE EFFECT OF GREAT COLD UPON MAGNETISM. BY JOHN TROWBRIDGE.

A $\mathbf{N}$ investigation upon the magnetic condition of steel and upon A the magnetic permeability of iron is now in progress in the Physical Laboratory of Harvard University. The preliminary experiments are interesting, since they show that very low temperatures exercise far greater influence on the magnetic condition than bas been noticed by previous observers.

It is stated by Wiedemann* that the cooling below the temperature at which steel is magnetized enfeebles the magnetic condition. A bar which was magnetized at $6^{\circ} \mathrm{C}$. or $8^{\circ} \mathrm{C}$. gave at $4^{\circ} \mathrm{C}$. and $-25^{\circ} \mathrm{C}$. intensities represented by 5.08 and $4 \cdot 90$. This represents a loss of less than 4 per cent. In my experiments the magnetic bar magnetized at $20^{\circ} \mathrm{C}$, when subjected to a tempera-

* Daguin, Traité de Physique, nouv. ed., "Influence de la température d'aimantation."

Phil. Mag. S. 5. Vol. 11. No. 69. May 1881. 
ture of about $-60^{\circ} \mathrm{C}$., loses a far greater percentage of its magnetism. In one case a bar magnetized to saturation lost 66 per cent. of its magnetism.

The low temperature was produced by solid carbonic acid and ether; and the magnetic moments of the bar were measured by placing it east and west of a suspended magnet which was provided with a mirror. In this case we have the magnetic moment

$$
M=\frac{1}{2} r^{2} T \tan \phi,
$$

where $r=$ distance of magnet, $\mathrm{T}=$ horizontal intensity of earth's magnetism, and $\phi=$ angle of deflection of suspended magnet. The angles were observed before the magnetic bar was surrounded with the freezing-mixture and afterwards at intervals when it was subjected, without removing it from its first position, to the influence of the carbonic acid. The following Table shows the variations of the deflections to which the magnetic moments are proportional.

When subjected to Freezing-mixture.

\begin{tabular}{|c|c|c|c|c|c|}
\hline $\begin{array}{l}\text { Before } \\
\text { freezing. }\end{array}$ & $\begin{array}{l}\frac{1}{2} \min . \\
\text { observ. }\end{array}$ & $\begin{array}{c}\text { After interval } \\
\text { of } 3 \frac{1}{2} \text { min. } \\
\frac{1}{2} \text { min. obs. }\end{array}$ & $\begin{array}{l}1 \text { min. } \\
\text { observ. }\end{array}$ & $\begin{array}{l}2 \min . \\
\text { observ. }\end{array}$ & $\begin{array}{l}5 \text { min. } \\
\text { observ. }\end{array}$ \\
\hline $\begin{array}{l}.6390 \\
.6395 \\
.6390\end{array}$ & $\begin{array}{r}\cdot 6050 \\
.6020 \\
.6000 \\
.5980 \\
.5960 \\
.5950 \\
.5940 \\
-5930 \\
.5920 \\
.5910 \\
.5900 \\
.5890\end{array}$ & $\begin{array}{r}5860 \\
\cdot 5850 \\
\cdot 5840 \\
\cdot 5840 \\
\cdot 5830 \\
\cdot 5820\end{array}$ & $\begin{array}{l}.5820 \\
.5815 \\
.5825 \\
.5815\end{array}$ & $\begin{array}{l}\cdot 5790 \\
\cdot 5740 \\
\cdot 5700 \\
\cdot 5650 \\
\cdot 5600\end{array}$ & $\begin{array}{l}\cdot 5540 \\
.5415 \\
.5480 \\
.5480\end{array}$ \\
\hline
\end{tabular}

The zero of the scale was 5000 ; and the observations are expressed in fractions of a metre. It will be seen that this bar lost in forty-seven minutes nearly two thirds of its original magnetic condition. After twenty-four hours' exposure to the temperature at which it had been magnetized, its magnetic condition was 50 per cent. of its original state.

A ring of soft iron was next experimented upon according to the method of Professor Rowland; and it was found that its magnetic permeability, on being subjected to very low temperature, differed greatly from the results obtained for soft iron at ordinary temperatures.

It is well stated by Dr. V. Strouhal and Dr. C. Barus, in a paper on the Physical Condition of Steel, Ann. der Physik und Chemie, 1880, No. 13, that we must regard each bar of steel, in regard to its magnetic condition, as an individual of special characteristics; and a long investigation will be necessary to determine the limits of the effect of cold upon magnetism. - Silliman's American Journal of Science, April 1881. 